\title{
Causes of Indian Basket Crude Oil Price Fluctuations and Its Impact on Indian Economy"
}

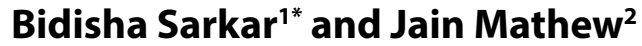 \\ ${ }^{1}$ Research Scholar, Department of Management Studies, Christ (Deemed to be University), \\ Bengaluru, 560029, Karnataka, India \\ 2Professor and Head, Department of Management Studies, Christ University, \\ Bengaluru, Karnataka, India
}

\begin{abstract}
Crude oil price fluctuation has become an emerging topic for the developing and oil importing countries. India is not an exception. Crude oil can be considered as one of the most influential natural resources in the world economy. Crude oil import dependency is one of the major economic issues for most of the countries. However, the oil exporting countries take this opportunity to perpetuate their economic power. Thus, the crude oil price fluctuation influences not only the oil importing and exporting countries but also the entire world economy in a significant way. Prime Minister Narendra Modi's recent United States of America (USA) visit has brought a noteworthy transformation in India's crude oil import trend. India has started importing crude oil from the USA. This recent phenomenon has enhanced the significance of this study to a greater extent as the composition of Indian basket crude oil price will be affected. The current Indian basket crude oil price is a composition of Dubai and Oman sour crude oil price and Brent sweet crude oil price benchmark. Probably, this composition is going to change in the near future. In this note, it is important to understand, how the global factors can influence this price benchmark. The paper aims to find out the factors influencing Indian basket crude oil price changes. Moreover, the paper attempts to investigate the impact of this price fluctuation on Indian economy. Overall, this study intends to explore the causes and consequences of international crude oil price changes of Indian basket. Assessing this cause and effect relationship requires a longterm historical data set. Hence, the timeframe of the research work has been considered from the financial year 2000-2001 to 2016-2017. Monthly data frequency has been employed for this research work. Oil Spreadsheet Model has been referred to understand the supplydemand mechanism which can be considered as the base for identifying the global factors, influencing Indian basket crude oil price changes. Econometric techniques (Granger Causality Test Model) have been adopted to understand the cause and effect relationship of this price fluctuation. It has been found that Organization of the Petroleum Exporting Countries (OPEC) and Brent crude oil prices have a bi-directional effect on an International crude oil price of Indian basket. On the other hand, the Indian basket crude oil price granger causes Gross Domestic Product (GDP). Several studies have been conducted to understand the connection between international crude oil price volatility and macroeconomic factors. However, minimal research work has been taken place to establish the same association with Indian basket crude oil price. Moreover, insignificant exploration has been noticed to investigate the global factors, influencing Indian basket crude oil price changes. In other way, it can be said that like other international crude oil price benchmarks, Indian basket crude oil benchmark has not been studied much. This paper attempts to reveal the influential factors associated with Indian basket crude oil price changes. Thus, it brings novelty in this field of research.
\end{abstract}

Keywords: Indian Basket Crude Oil Price, Price Fluctuation, Indian Economy, Import

*Email: bidisha.sarkar@res.christuniversity.in, jainmathew@christuniversity.in

"This is the revised and modified version of the article, originally presented in the 3rd International Conference on Economic Growth and Sustainable Development: Emerging Trends, SDMIMD, November 2017. 


\section{Introduction}

India is an emerging economy with a Gross Domestics Products (GDP) growth of $5-10 \%$ per annum. Moreover, the recent business reforms, initiated by Prime Minister Narendra Modi may bring in changes in the Indian Economy. Business reforms further indicate the possibility of energy consumption. Crude oil is the second highest source of India's energy consumption with $23 \%$ of the share after Coal. The recent scenario of Indian crude oil segment is not appreciable. On one hand where crude oil consumption is increasing, on the other hand, the production is declining. It results in more import expenses. In this context, the major difference with the developed countries is crude oil dependency. This is an alarming situation and India should start taking initiatives towards alternative energy sources.

Sadorsky (1999) has disclosed the bidirectional connection between crude oil price and economy. $\mathrm{He}$ has found an asymmetric effect of crude oil volatility shocks on economic activities. According to the researcher, both the fluctuations in crude oil price and changes in economic activities have an impact on each other. Guo and Kliesen (2005) have found that crude oil price fluctuation influences aggregate economic events through relative dollar price changes of crude oil. Hence, it proves that there is a scope of understanding the connection between crude oil price and economic activities. The oil price shocks over the last four decades have been driven by several causes and that deconstructed the international oil market. Soni (2014) has reported few shocks along with their possible reasons. According to the author, the restriction imposed by Arab countries and formation of OPEC is responsible for early 1970's shocks. Formation of OPEC brought control mechanism over the marginal production to regulate the crude oil prices. Subsequently, Iran-Iraq war in 1979 enhanced the crude oil price. Then in late 1990's, a supply shock driven by Iraqi attack on Kuwait had been witnessed. In the year 2001, Iraq suspended it's crude oil export to respond on sanction from West. After that, few more price hike had been experienced led by certain supply shocks. According to the author, most of the price hikes and losses occurred due to the physical disruption of crude oil supply. He did not blame market control mechanism of oil producers and political events for the price hike. However, in recent past, integration of crude oil market and incorporation of crude oil as a worldwide traded commodity, succeeded to fight against supply shortage in short run but the effect has been manifested as a price hike in the long run.

The price fluctuation of crude oil has a channelizing impact on the world economy. A hike in crude oil price increase the heating and transportation cost. Thus, the cost of production rises resulting in the price hike. It provokes the apprehension about inflation among the consumers. It further affects the discretionary spending of consumers. Eventually, a negative impact on macroeconomy has to experience. Moreover, a huge import bill can adversely affect the foreign exchange reserve of a nation. This situation cannot be avoided, but a proper prediction can reduce the risk as well as economic loss. India experiences several transformations in the field of oil throughout the financial year 2017-18. It includes dynamic pricing mechanism and import from the United States of America. All these transformations are directly linked with the crude oil pricing mechanism. Thus, the relevance of this paper becomes prominent at the current Indian scenario.

India's excessive import dependency on crude oil brings several international factors into the consideration. Frequent price fluctuations and price hike of international crude oil can enhance the import bill of India which will lead to a hike on trade deficit and thus eventually, Indian economy will be affected. It demonstrates how the international factors can influence the domestic economy. Proper policy implication can not be advised without diagnosing the cause and effect of the issue. Therefore, the study aims to investigate the factors influencing Indian basket crude oil price. It further intends to understand how the Indian economy will be affected due to the crude oil price changes.

\section{Problem Statement}

Domestic crude oil production declines whereas the domestic crude oil consumption is rocketing. It creates a 
huge gap between the demand and supply. Import is the only solution for bridging this gap. With the increment of Indian basket crude oil price, the import will be costlier for India. Hence, a rise in the international crude oil price of Indian basket has become the matter of concern, and it may have a devastating effect on Indian economy. According to Bhattacharjee (2013), it is necessary to understand the consequences of crude oil price changes on nation's economy.

\section{Scope of the Study}

The effect of crude oil price changes has been captured in the Indian context. The three major international crude oil price benchmarks are Brent Crude (European), West Texas Intermediate crude oil (U.S.) and OPEC Basket. In this paper, international crude oil price of Indian basket has been explored. The time span of the study is the financial year 2000-2001 to 2016-2017. Data frequency for the research work is monthly. Oil spreadsheet model has been referred for the selection of factors influencing international crude oil price (Brook et al., 2004). Before proceeding to the next segment, it is important to conceptualise two indispensable elements of this paper.

\section{Operational Definitions}

Few terminologies require further explanation to develop better understanding. The frequent and vital terms has been discussed as follows:

\subsection{International Crude Oil Price of Indian Basket}

International Crude Oil Price of Indian Basket is considered as an indicator of India's crude oil import price. It is the composition of Oman and Dubai Benchmark and Brent Benchmark. Crude oil is classified into two segments, sweet and sour grades and it depends on the amount of sulphur, diluted in it. The sweet grade crude oil contains less amount of sulphur. In contrast, sour grade crude oil needs additional processing cost for its higher amount of sulphur content. Oman and Dubai basket is a sour grade crude oil whereas Brent basket is a sweet grade crude oil. Hence, Indian crude oil basket is a combination of both sweet and sour grade crude oil. The weighted average of the Oman-Dubai Benchmark (68.2\%) and Brent Benchmark $(31.8 \%)$ is termed as the International Crude Oil Price of Indian Basket. It is one of the major elements considered by the Indian Government while assessing the domestic price issues.

\subsection{Oil Spreadsheet Model}

Oil spreadsheet model consists of two broad constructs, global crude oil supply and demand. According to the model, global supply indicates OPEC and Non-OPEC countries' production. Regarding global demand, the model describes demand from OECD and Non-OECD countries' oil consumption. However, the scope of this paper is restricted to the Indian context. Hence, only crude oil and petroleum product consumption of India have been taken into consideration.

\section{Theoretical Backdrop}

Pricing mechanism theory may provide sufficient aid to develop the model. Signaling, transmission of preferences and rationing are two important functions of the pricing mechanism. Now, it is important to understand, how these functions are related to the crude oil pricing strategies. Signaling function indicates that price fluctuations provide information to the producers and consumers regarding the demand and supply mismatch. Price fluctuation is one of the most observable phenomena in the crude oil field. Price gives a signal to the oil-producing countries to inflate their production to meet higher demand. On the other hand, price fall due to the excess supply is a signal to enhance importer base. Transmission of preferences of oil importing countries is very much required for crude oil exporters. They should always keep an eye on the economic growth of the importers. It may help the oil producers to predict the crude oil demand and develop the production strategy accordingly. Rationing is an utmost requirement for the scarce resources.

Keynesian's inflation theory may provide enough sustenance to the theoretical framework. In a narrower aspect, price hike means inflation whereas the broader view of inflation also indicates excess money in consumers' hand. However, inflation is not a desired economic phenomenon and government usually takes 
preventive measures for that. Demand-pull and costpush are two major causes of inflation. The connection between the crude oil price hike and inflation theory is attempted to be justified in this section. Crude oil price hike leads to an increment in transportation and heating cost. These are necessary expenses for most of the products. Hence, cost of production increases. Thus, the price hike takes place, and this is how costpush inflation occurs.

Figure 1, depicts that crude oil price hike is a sufficient cause of inflation. One of the major problems of inflation is deterioration of purchasing power. Thus, industrial production starts declining and along with that gross domestic product and other macroeconomic factors also get affected.

\section{Review of Literature}

Based on the aforementioned objectives, literature has been segregated into two segments, factors influencing international crude oil price and factors affected by the crude oil price, in the Indian context. It indicates the causes and effect of international crude oil price changes for Indian basket.

\subsection{Factors Influencing International Crude Oil Price Changes}

Gulen and Foss (2012) have acknowledged the existence of several global attributes with the potential to affect the crude oil price significantly at a particular point in time. Few constructs have been pointed out by the researchers that have significant impact on crude oil price. The first construct is the demand which is the aggregate of consumption and inventory. It has bidirectional impact on the refining process. The second construct is the composition of 'access to the resources' and operation of National Oil Companies (NOCs). The third construct incorporates the financial market that enlightens the positions of heterogeneous traders in the derivative market in connection with Over-thecounter (OTC) transactions. In line with extracting the factors, Energy Information Administration (2018), has come up with seven factors driving crude oil price. Geopolitical and economic events; arbitrage, global oil consumption; Non-OPEC production, Saudi-Arabia crude oil production; OPEC's spare production and unplanned supply disruptions are those seven factors. Concurrently, Dougher (2015), has pointed out several other elements affecting crude oil price and those are weather; exchange rates and inflation; speculation, hedging and investment; inventories and OPEC production decision. However, an article published by Government of Canada (2010), segregates the factors into two divisions, traditional and emerging factors. The traditional factors are, severe weather events; oil supply and demand changes; OPEC production decision; OPEC spare capacity levels; U.S. commercial crude oil inventory levels; the marginal cost of production; refinery infrastructure and the impact of technological changes on oil price. In contrast, the emerging topics are Asian oil demand; oil price subsidies; hypersensitivity to geopolitical events; national oil companies (NOCs); the declining value of the US dollar; disappointing nonOPEC production and Gulf of Mexico oil spill. King, Deng and Metz (2012) segmented the factors into three constructs, namely, political events and governmental decisions; economic factors and natural events. Here, political events are the combination of monetary policy actions, OPEC announcements, political instability and changes in demand subsidies in abroad. Economic factors have also taken into consideration and those are inventory announcement, financial trading, speculation and alleged market manipulation. The last construct, natural events contains the extreme weather event that disrupts offshore production and changes in temperature. In this segment, several breakdowns of constructs have been depicted in the form of the

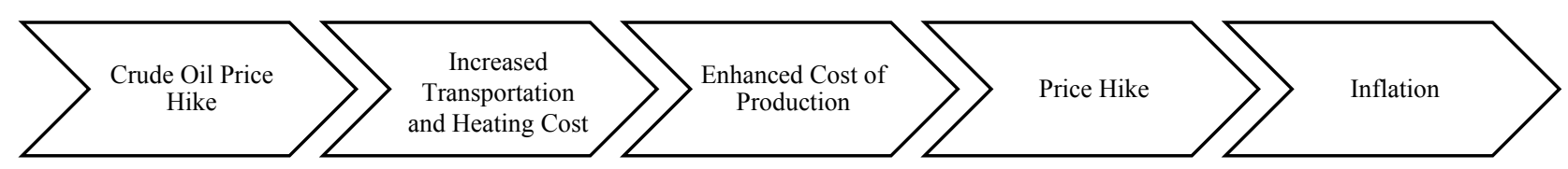

Note. Self Constructed Figure

Figure 1. Sequential Relationship between Crude Oil Price Hike and Inflation 
factors affecting crude oil prices. Sharma, Singh, Sharma and Gupta (2012) reports production, natural causes, inventory and demand as the factors affecting crude oil price. In agreement with the above factors Jain (2013), has incorporated one more factor, supply. The authors try to exhibit a holistic scenario of crude oil price volatility. The paper begins with identifying factors influencing crude oil price changes followed by discussing its impact on Indian economy. Moreover, authors have thoroughly discussed the steps taken by the Indian Government and Reserve Bank of India (RBI) to reduce the adverse impact of crude oil price changes. The research paper has assessed the impact of crude oil price on GDP and inflation. The researchers have come up with few initiatives taken by the Indian government, and those are, start searching for alternate energy, providing a subsidy to the oil companies and domestic price hike of diesel and petrol. Furthermore, the paper has revealed the steps taken by RBI as hike of Cash Reserve Ratio (CRR) and Repurchase Agreement (REPO) Rate. Srithar, Bairavi and Mariselvam (2015) have also tried to portray a broader view of crude oil price. According to the researchers, the factors influencing crude oil price are geopolitics; speculative buying and selling; OPEC output; increased demand from developed and emerging countries; weather conditions; change in the refining sector; currency fluctuation and supply and spare capacity. However, Dougher (2015) acknowledges that though there are several attributes influencing crude oil price eventually, it comes down to the demand and supply. Few prominent international crude oil price benchmarks had been taken into account for most of the above literatures. However, none had considered the Indian basket crude oil price to undertake the research.

\subsection{Factors Influenced by International Crude Oil Price Changes: Indian Context}

The previous section exhibits a holistic approach to crude oil price mechanism. On contrast; this segment focuses on the impact of crude oil price changes on Indian economy. In the study of Gupta (2008), India has been found as the most vulnerable country regarding crude oil price. He computed the Oil Vulnerability Index over 26 countries. Bacon and Kojima (2008) have mentioned in their decomposition analysis that
India's vulnerability to oil prices has a sharp increase; from 2.6 in 2001 to 4.4 in 2006. A combination of factors is held responsible for this situation. According to the authors, the rise in oil import, hike in oil price and exchange rate have driven the vulnerability. Bhattacharya and Batra (2009), contributes towards the relationship between international crude oil price and few macroeconomic variables such as money supply, exchange rate, industrial production and WPI. In line with it, the contribution of Bhanumurthy, Das and Bose (2012) with a macroeconomic model can be considered. According to the researchers not only the growth trajectory, few other macroeconomic indicators such as government revenue, inflation and current account deficits are also driven by the oil price deregulation. Aparna (2014) considers Gross Domestic Product (GDP), Index of Industrial Production(IIP) and Wholesale Price Index (WPI) as the relevant variables to study the impact of crude oil price change. The author finds an immediate negative effect on the GDP and IIP hike with a positive change in the crude oil price. In contrast, a positive impact on WPI has been revealed. However, Srithar et al. (2015) have undertaken three factors to examine the impact of crude oil price, and those are inflation, the stock market and GDP. The outcome of the study reveals a positive impact of crude oil changes on all the three factors. In contrary, Jain (2013), has found a moderate relationship between the crude oil price and inflation. A wide range of economic variables had been studied by different authors but no one attempted to analyse the impact of Indian basket crude oil price on nation's economy.

\subsection{Research Gap}

These studies do not pay much attention to the holistic approach of input selection and the effect of crude oil price change on several economic variables. Furthermore, the previous researchers have either explored the factors influencing crude oil price changes or its consequences to a particular or set of economies. Few researchers have worked broadly on both the attributes. Hence, a holistic approach could not be captured from the previous work done in this field. Moreover, the majority of the research works are based on the international crude oil price benchmark, such as WTI and Brent. Thus, the Indian basket benchmark of 
crude oil prices has been ignored. In this study, a broader perspective of global and Indian factors has presented. Unlike other studies, here, more attention is paid to the factor influencing international crude oil price of Indian basket and its effect on several Indian factors. Thus, a proper cause and effect study has conducted.

\section{Methodology}

In this section, data structure, sources, time frame and data frequency are discussed.

\subsection{Data Structure}

The empirical research work has been broadly segmented into two sections. The first part has investigated the causes of crude oil price changes by finding out the factors influencing international crude oil price of Indian basket. On the other hand, the second has assessed the impact of that price changes on Indian economy. Section one consists of seven variables, out of those, international crude oil price change of Indian Basket is the dependent variable. The regressors can be categorised into two constructs, global oil supply and Indian oil demand. Global oil supply has been measured by OPEC and Non-OPEC productions and three major price benchmarks, OPEC, Brent and WTI. In contrast, oil demand in India has been measured by consumption of crude oil and petroleum products. Oil Spreadsheet Model has been referred to understand the supply-demand mechanism. This model talks about global demand and supply. However, in this paper, impact on Indian economy has been explored. Hence, the scope has been restricted to only Indian demand. In contrast, the majority of India's crude oil demand is satisfied by imports. Therefore, global factors have to be considered. The second section of the paper incorporates Indian economy as its sole construct which contains four macroeconomic variables, GDP, inflation, industrial production and foreign exchange reserve.

\subsection{Data Sources}

Several national and international secondary databases have been explored for the study. Government websites have been given the priority. In case of its absence, widely referred websites have been explored.

Table 1. Data Structure and Sources of Factors Influencing International Crude Oil Price of Indian Basket

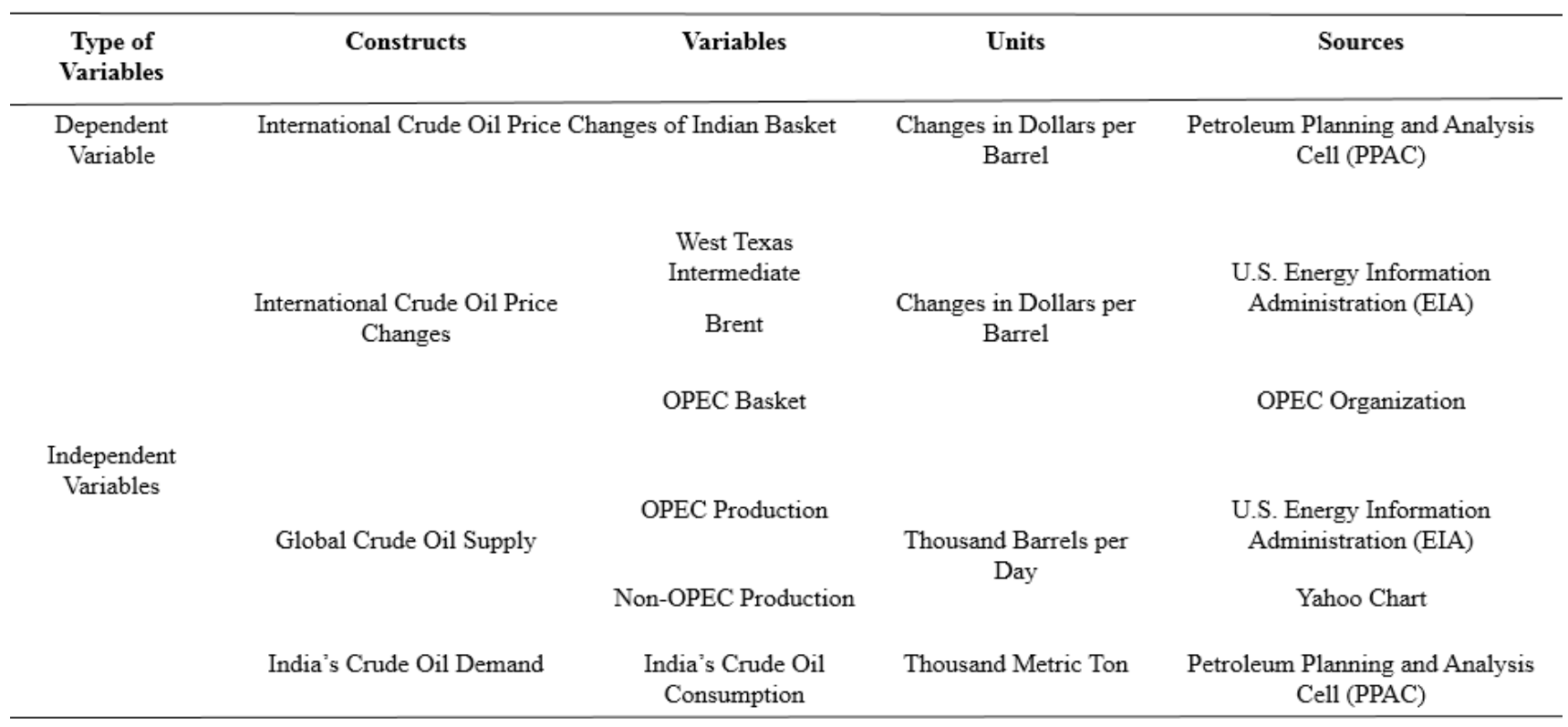

Note. Self-constructed Table 
Table 2. Data Structure and Sources of Factors Influenced by International Crude Oil Price of Indian Basket

\begin{tabular}{|c|c|c|c|}
\hline Types of Variables & Variables & Source & Units \\
\hline \multirow{4}{*}{ Dependent Variables } & Inflation & OECD Website & Wholesale Price Index (WPI) \\
\hline & Gross Domestic Production & & Billions of Indian Rupees \\
\hline & Foreign Exchange Reserve & $\begin{array}{c}\text { Website of Reserve Bank of } \\
\text { India }\end{array}$ & Million US Dollars \\
\hline & $\begin{array}{l}\text { Index of Industrial } \\
\text { Production }\end{array}$ & & \\
\hline Independent Variable & $\begin{array}{l}\text { International Crude Oil Price } \\
\text { Changes of Indian Basket }\end{array}$ & $\begin{array}{l}\text { Petroleum Planning and } \\
\text { Analysis Cell (PPAC) }\end{array}$ & $\begin{array}{c}\text { Changes in Dollars per } \\
\text { Barrel }\end{array}$ \\
\hline
\end{tabular}

Note. Self-constructed Table

\subsection{Time Frame}

16 years long time frame has been used for this scholarly work. According to Bhattacharjee (2013), the financial year 2000 to 2009 , this time frame has huge significance on crude oil history. The occurrence during this span are as follows:

- Dismantling of the Administered Price Mechanism (w.e.f 1 April 2002)

- Devastating Hurricane Katrina, 2005 (Caused \$12 billion damage on the U.S. Gulf Coast)

- OPEC Supply Shock (Since it is an influencing factor in global crude oil price changes)

- Financial Crisis, 2008

One more milestone can be incorporated to justify the extended time frame from 2009 to 2017 financial year.

Massive Price Fall of Crude Oil, 2014 (approximately by $44 \%)$

\subsection{Data Frequency}

Data frequency for this study is monthly data. Arouri and Nguyen (2010), have explained the issues with daily data. Use of monthly data, significantly minimise the biases of bid-ask effect and non-synchronous trading days. On the contrary, weekly data may have issues of asymmetry in response to the oil price shocks. According to the experts, uniformity in data frequency should be maintained throughout the research work. Unlike developed countries, India is not updating its fiscal and monetary data very frequently. Hence, it is difficult to get macroeconomic data on the daily and weekly basis. The above argument advocates the adoption of monthly data.

\section{Analysis and Discussion}

In the methodology section, it has been mentioned that the data set is time series in nature. Stationarity check is the initial step for any time series data, and unit root 
is one of the widely adopted tests for this purpose. Augmented Dickey-Fuller Test has been applied to check the stationarity. It has been found that even after two differences all the variables do not become stationary. Hence, a structural break analysis has been conducted for all four sets of equations under section two. Chow test has been considered to determine the presence of structural break. In this test null hypothesis is as follows:

$\mathrm{H}_{0}$ : The model does not have structural differences

Table 3. Structural Break Analysis [Chow Test]

\begin{tabular}{|l|l|l|}
\hline Combination & $\begin{array}{l}\mathrm{P} \text { value at 2000:04 } \\
\text { to 2017:03 }^{\mathrm{a}}\end{array}$ & $\begin{array}{l}\mathrm{P} \text { value at 2007:04 } \\
\text { to 2017:03 }\end{array}$ \\
\hline $\begin{array}{l}\text { Indian Basket Crude Oil Price: } \\
\text { Inflation }\end{array}$ & 0.0000 & 0.5279 \\
\hline $\begin{array}{l}\text { Indian Basket Crude Oil Price: } \\
\text { GDP }\end{array}$ & 0.0000 & 0.0008 \\
\hline $\begin{array}{l}\text { Indian Basket Crude Oil Price: } \\
\text { Foreign Exchange Reserve }\end{array}$ & 0.0000 & 0.1432 \\
\hline $\begin{array}{l}\text { Indian Basket Crude Oil Price: } \\
\text { Industrial Production }\end{array}$ & 0.0000 & 0.9820 \\
\hline
\end{tabular}

Note. Self-constructed with the results generated by the econometrics software Gretl

${ }^{a}$ at $95 \%$ signiaaficance level. ${ }^{b}$ at $95 \%$ significance level.

In all the cases p-value is lesser than 0.05 which indicates to reject the null hypothesis at $95 \%$ significance level. It infers that the models have structural differences and to deal with these issues, few steps can be taken, such as add or deduct data and find out outliers from the data set. An international crude oil price of Indian basket contains several outliers throughout the data set those can also be considered as the shocks. On the other hand, the 2000-2001 financial year is the maximum time frame till when data for all the variables are available. Hence, option for adding up data has to be discarded. Taking into consideration all these arguments, the data set has been deducted till 2007-2008 financial year. It infers ten years of monthly data [i.e. 120 observations].

\subsection{Co-Integration Test}

All the variables are integrated at level one and co-integration is one of the widely adopted tests for this category. Establishing a co-integrated relationship requires two criteria to be satisfied and those are as follows:

a. The unit-root hypothesis is not rejected for the individual variables and

b. The unit-root hypothesis is rejected for the residuals (uhat) from the cointegrating regression.

It can also be expressed as an equation. If $\mathrm{Yt}$ and $\mathrm{Xt}$ are the dependent and independent variables, respectively and are not stationary at level.

$Y_{t}-X_{t}=U_{t}$ [where $U_{t}$ is the linear combination of $Y_{t}$ and $\left.X_{t}\right]$

$\mathrm{Y}_{\mathrm{t}}$ and $\mathrm{X}_{\mathrm{t}}$ will be co-integrated only if $\mathrm{U}_{\mathrm{t}}$ is stationary.

In this case, the outcome of the ADF unit root test is important to refer. Hence, all the required fields have been demonstrated in a tabular format.

Table 4. Augmented Dickey-Fuller Unit Root Test Results

\begin{tabular}{|c|c|c|}
\hline \multirow[t]{2}{*}{ Variables } & \multicolumn{2}{|c|}{ ADF Unit Root Test Result } \\
\hline & $P$ Value at Level a & $P$ Value at $1^{\text {st }}$ Difference ${ }^{b}$ \\
\hline $\begin{array}{l}\text { International Crude oil Price } \\
\text { (Indian Basket) }\end{array}$ & 0.3348 & $1.882 \mathrm{e}-007$ \\
\hline OPEC Production & 0.8779 & $4.076 \mathrm{e}-041$ \\
\hline Non-OPEC Production & 0.958 & 0.05216 \\
\hline OPEC Price & 0.3828 & $6.35 e-009$ \\
\hline Brent Price & 0.3773 & $6.009 \mathrm{e}-012$ \\
\hline WTI Price & 0.36 & $5.429 e-012$ \\
\hline Consumption & 0.9999 & 0.01296 \\
\hline Inflation & 0.3911 & 0.0001 \\
\hline GDP & 0.9999 & 0.0588 \\
\hline Foreign Exchange Reserve & 0.2041 & 0.0002 \\
\hline Industrial Production & 0.3594 & 0.0263 \\
\hline
\end{tabular}

Note. Self-constructed with the results generated by the econometrics software Gretl

${ }^{a}$ at $95 \%$ significance level. ${ }^{b}$ at $95 \%$ significance level

Table 4 exhibits that all the variables of two sections of the study are not stationary at level and after first difference, the variables have become stationary. 


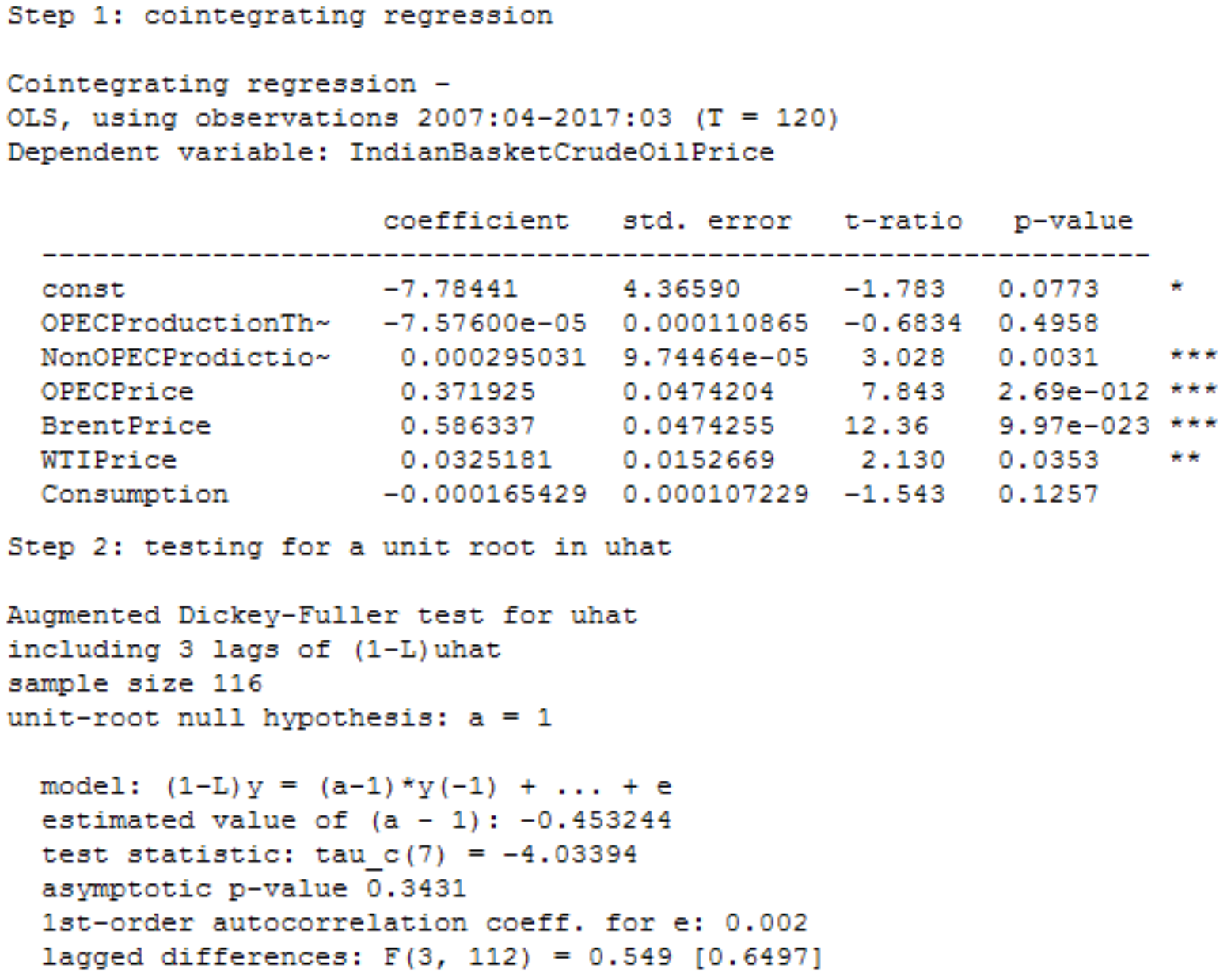

Note. Output generated by econometrics software Grtle

Figure 2. Outcome of Co-Integration Test for Factors Influencing International Crude Oil Price of Indian Basket.

Table 5. Outcome of Co-Integration Test for Factors Influenced by International Crude Oil Price of Indian Basket

\begin{tabular}{|l|l|}
\hline Combinations & $\begin{array}{l}\text { P-Value of Residuals at ADF } \\
\text { Unit Root Test }\end{array}$ \\
\hline $\begin{array}{l}\text { International Crude oil Price (Indian Basket) } \\
\text { and Inflation }\end{array}$ & 0.3902 \\
\hline $\begin{array}{l}\text { International Crude oil Price (Indian Basket) } \\
\text { and GDP }\end{array}$ & 0.9092 \\
\hline $\begin{array}{l}\text { International Crude oil Price (Indian Basket) } \\
\text { and Foreign Exchange Reserve }\end{array}$ & 0.2212 \\
\hline $\begin{array}{l}\text { International Crude oil Price (Indian Basket) } \\
\text { and Industrial Production }\end{array}$ & 0.5618 \\
\hline
\end{tabular}

Note. Self-constructed with the results generated by the econometrics software Gretl

${ }^{a}$ at $95 \%$ significance level
From figure 2 and table 5, it is evident that co-integrating relationships cannot be established. Unit root hypothesis is not rejected in case of all the individual variables as in all cases $P$ values are greater than significance level. Hence, the first criterion of the co-integrating relationship has been satisfied. However, the unit root null hypothesis has not been rejected for the residuals which are the second condition to be co-integrated. It indicates that the variables are not cointegrated. It infers that no long-term relationship is available among the dependent and independent variables of both the sections.

\subsection{Granger Casualty Test}

In case, the dependent variable is ganger caused by an independent variable; it infers that past values of 
regressors can effect and forecast the future value of dependent variable. The null hypothesis for granger casualty test is as follows:

$\mathrm{H}_{0}$ : Independent variable does not Granger cause the dependent variable

The most suitable lag has been determined by the Vector Autoregression Lag Selection test, and it is three for both the sections.

The output of the granger casualty test, demonstrated in the table 6, depicts that there is an evidence of casualty for two bi-directional combinations. Brent and OPEC price have granger causes on international crude oil price of Indian basket and vice versa. This result is evident as the Indian basket benchmark is a weighted average of Brent and Oman-Dubai crude oil price benchmarks. However, jointly all the regressors granger cause international crude oil price of Indian basket. It is apparent from the above discussion that
Brent and OPEC have an impact on the Indian basket benchmarks. Furthermore, the outcome also reveals that based on individual historical values of OPEC and Brent benchmark, Indian basket crude oil price can be determined and predicted. Moreover, a combination of all the independent variables can provide a better prediction.

It has been evident from table 7, that none of the variables have a bidirectional causal relationship. Only in two cases, evidence for unidirectional granger casualty has been noticed. An international crude oil price of Indian basket granger causes GDP of India. This is how one objective of the study is satisfied. However, being world's third-largest crude oil consumer, a bidirectional linkage could be expected. In addition to that foreign exchange reserve granger causes international crude oil price of Indian basket. Though it is beyond the objective of the study but an important inference can be extracted out of it. India's import dependency is more than $75 \%$, and it is ever

Table 6. Outcome of Granger Casualty Test of Factors Influencing International Crude Oil Price of Indian Basket

\begin{tabular}{|l|l|l|l|l|}
\hline Direction of Causality & Number of Lags & F Statistics & P Value $^{\text {a }}$ & Decision \\
\hline OPEC Production $\rightarrow \quad$ International Crude Oil Price of Indian Basket & 3 & 0.80073 & 0.4965 & Accepted \\
\hline NON-OPEC Production $\rightarrow \quad$ International Crude Oil Price of Indian Basket & 3 & 0.41857 & 0.7401 & Accepted \\
\hline OPEC Price $\rightarrow \quad$ International Crude Oil Price of Indian Basket & 3 & 3.96253 .3835 & 0.01040 .0214 & Rejected \\
\hline Brent Price $\rightarrow \quad$ International Crude Oil Price of Indian Basket & 3 & 2.57812 .6549 & 0.05430 .0530 & Rejected \\
\hline WTI Price $\rightarrow \quad$ International Crude Oil Price of Indian Basket & 3 & 1.0338 & 0.3813 & Accepted \\
\hline Consumption $\rightarrow \quad$ International Crude Oil Price of Indian Basket & 3 & 0.54405 & 0.6534 & Accepted \\
\hline Combination of All Variables $\rightarrow$ International Crude Oil Price of Indian Basket & 3 & 2.9854 & 0.0071 & Rejected \\
\hline
\end{tabular}

Note. Self-constructed with the results generated by the econometrics software Gretl

a at $95 \%$ significance level

Table 7. Outcome of Granger Casualty Test of Factors Influenced by International Crude Oil Price of Indian Basket

\begin{tabular}{|l|l|l|l|l|}
\hline Direction of Causality & Number of Lags & F Statistics & P Value $^{\text {a }}$ & Decision $^{-1}$ \\
\hline International Crude Oil Price of Indian Basket $\rightarrow$ Inflation & 3 & 0.17422 & 0.9136 & Accept \\
\hline Inflation $\rightarrow$ International Crude Oil Price of Indian Basket & 3 & 0.40139 & 0.7523 & Accept \\
\hline International Crude Oil Price of Indian Basket $\rightarrow$ GDP & 3 & 2.6444 & 0.0526 & Reject \\
\hline GDP $\rightarrow$ International Crude Oil Price of Indian Basket & 3 & 0.46724 & 0.7057 & Accept \\
\hline International Crude Oil Price of Indian Basket $\rightarrow$ Foreign Exchange Reserve & 3 & 1.2806 & 0.2845 & Accept \\
\hline Foreign Exchange Reserve $\rightarrow$ International Crude Oil Price of Indian Basket & 3 & 4.0698 & 0.0087 & Reject \\
\hline International Crude Oil Price of Indian Basket $\rightarrow$ Industrial Production & 3 & 0.98799 & 0.4012 & Accept \\
\hline Industrial Production $\rightarrow$ International Crude Oil Price of Indian Basket & 3 & 0.51586 & 0.6722 & Accept \\
\hline
\end{tabular}

Note. Self-constructed with the results generated by the econometrics software Gretl

a at $95 \%$ significance level 
increasing. Import and foreign exchange rates are inseparable attributes. Hence, it is evident that foreign exchange reserves of major oil importing countries like India effect international crude oil price and thus the prices for Indian basket. There is significant theoretical evidence to prove the relationship between the inflation and international crude oil price of Indian basket. However, the granger casualty test does not provide any empirical pieces of evidence for the association.

\section{Conceptual Model}

Based on the above discussion and empirical evidence the conceptual model has been developed.

Now when the outcome of the empirical investigation is apparent, the actual relationship between the variables can be cross checked with the help of a graph which is constructed by raw data without any differences.

Figure 4 exhibits the movement of the two major international benchmarks of crude oil along with Indian basket. The graph is enough to justify the empirical outcome. It can also be inferred from the graph that Brent crude oil price has been higher than the other two benchmark in the majority of the time span. A probable reason for that could be its better quality. OPEC crude oil price has always been lower through the assessment period. However, the current scenario is not the same as the OPEC has cut down its production. OPEC crude oil price has been increased, and their production cut decision left the entire world to experience a havoc demand-supply mismatch. However, India has taken a wise decision to import crude oil from the USA which is beneficial to maintain the Indian basket crude oil price.

\section{Scope of Further Study}

Apart from the associations above, few other causal relationships have been found out, those are beyond the scope of this paper but could be considered for the future studies. OPEC crude oil price granger causes Brent and WTI crude oil price with a p-value of 0.0224 and 0.0519 respectively. Hence, the interdependence and association among the major global crude oil prices can be studied. Another surprising outcome is that crude oil consumption of India granger causes the non-OPEC production of crude oil. India is third largest crude oil consumer in the world. Therefore,

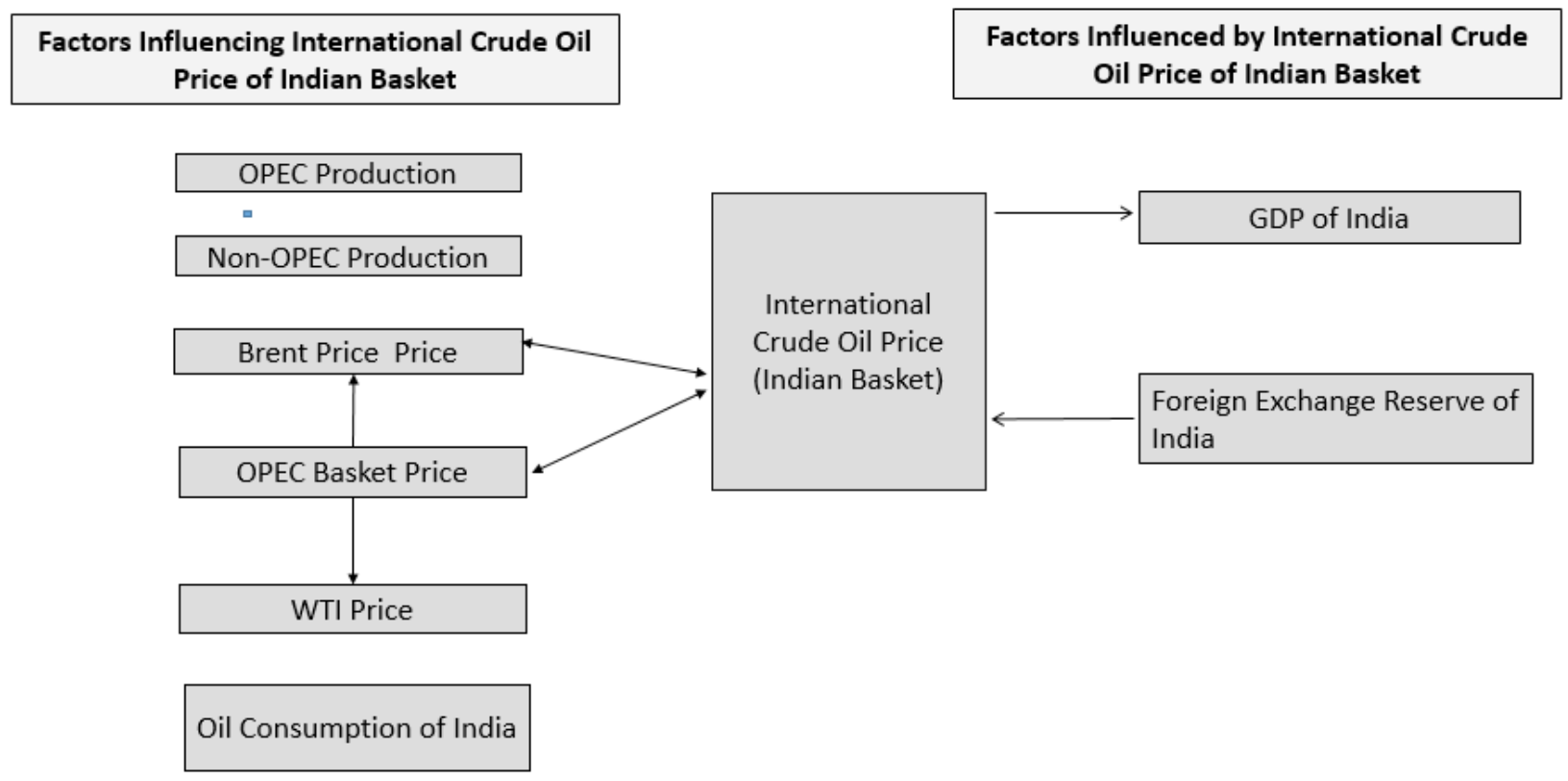

Note. Self-constructed Figure

Figure 3. Conceptual Model. 


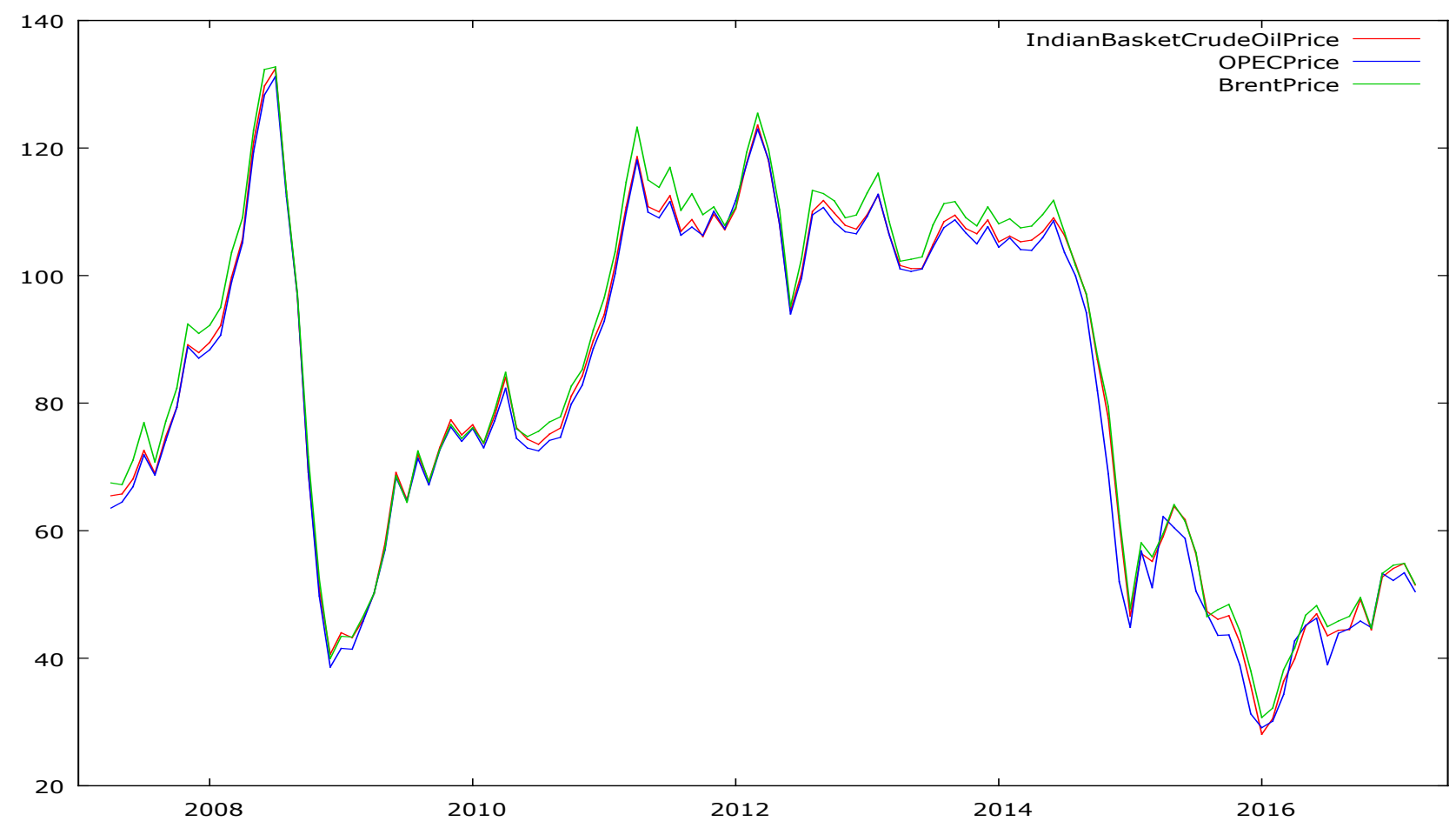

Note. Extracted from Grtle Econometrics Software

Figure 4. Graphical Representation of Brent, OPEC and Indian Basket Crude Oil Benchmark.

India's crude oil consumption can be considered as the significant factor for global crude oil demand. Thus, there will be a possibility to explore the relationship between major importers' crude oil consumption and global crude oil production as it is important to maintain the demand-supply equilibrium. Moreover, since several granger casualty relationships have been established here, prediction of Indian basket crude oil price would be easier.

\section{Conclusion}

Gyagri, Amarfio and Marfo (2017) considered OPEC as one of the major factor accounted for crude oil price changes. Punati and Raju (2017) had come up with the same outcome. The findings of this study revealed that OPEC price is influencing Indian basket crude oil price whereas there is no evidence of OPEC production impacting the same. On contrast, evidences from literatures shown that it is not only OPEC price but OPEC as a cumulative power influence crude oil price which includes OPEC production, refinery capacity and few other factors. This difference can be justified. The previous studies had been done on international crude oil price whereas the main focus of this study is on Indian basket crude oil price. There is a possibility that changes in price benchmark brought the difference. It has been found that Brent crude oil price is influencing Indian basket crude oil price. Most of the previous studies had considered Brent as a benchmark of international crude oil price and analysed the demand and supply mechanism on it. However, Punati and Raju (2017) had found it an influencing factor for domestic crude oil price of India. On the other hand, the outcome of this study that Indian basket crude oil price can influence GDP of the nation, can also be substantiate by the research work of Aparna (2014) and Srithar et al. (2015).

Based on the above discussion few policy implications can be discussed pertaining to India. The outcome of this research work revealed that Indian basket crude 
oil price is influenced by Brent and OPEC crude oil price. Brent benchmark actually belongs to European zone and the political bonding of India with this region is stable. Moreover, the global oil industry did not witness much fluctuation due to this benchmark. On the other hand, OPEC has given several shocks to this industry. The organisation often come up with frequent production cut decision and leaves an adverse impact on industry. Financial year 2017-18 is an evidence of this phenomenon and the impact is visibly reflected through the 50\% (approximately) crude oil price hike in last one year. Moreover, OPEC's recent battle with US provides another dimension to the issue. On the other hand, the study revealed the connection between the Indian Basket crude oil price and GDP. It infers that OPEC price shocks can eventually affect the Indian economy. Considering the frequent production cut and unfavorable political connections of OPEC, it can be suggested to reduce the import dependency on OPEC. It can not only reduce the trade deficit, but also can balance the vulnerability in Indian Oil industry.

The study intends to provide a holistic picture of the given issue, crude oil price changes. Both the factors influencing crude oil prices and factors affected by crude oil prices have been taken into consideration. It is very difficult to integrate two independent models in one research work. However, its novelty and holistic approach provides a different dimension to it. Several empirical pieces of evidence have been exhibited throughout the paper and based on that a conceptual model has also been developed. It would have been better if the conceptual model and theoretical model were complimenting to each other. However, that has not been possible due to the absence of empirical evidence for a relationship such as crude oil price and inflation. The outcome of the study and the conceptual model can be considered as a base for several other potential future studies.

\section{Bibliography}

Aparna, A. (2014). Impact of Oil Prices on the Indian Economy. NMIMSMR, XXIII, 141-7.

Arouri, A. H., \& Nguyen, D. K. (2010). Oil Prices, Stock

Markets and Portfolio Investment: Evidence from Sector
Analysis in Europe over the Last Decade. Energy Policy, 38(8), 4528-39.

Bacon, R., \& Kojima, M. (2018). Vulnerability to Oil Price Increases: A Decomposition Analysis of 161 Countries. World Bank. Washington D.C.: World Bank.

Bhanumurthy, N. R., Das, S., \& Bose, S. (2012). Oil Price Shock, Pass-through Policy and its Impact on India. National Institute of Public Finance and Policy, $1-47$.

Bhattacharjee, P. (2013). A Study of the Impact of Crude Oil Prices on Indian Economy. Doctoral Dissertation, Dr D. Y. Patil University, Mumbai, India. Available at: http:// www.dypatil.edu/schools/management/wp-content/ uploads/2015/05/A-STUDY-OF-THE-IMPACT-OFCRUDE-OIL-PRICES-ON-INDIAN-ECONOMYPankaj-Bhattacharjee.pdf.

Bhattacharya, BB, \& Batra, A. (2009). Fuel Pricing Policy Reform in India: Implications and Way Forward. Economic \& Political Weekly, XLIV (29), 1-10.

Brook, A. M., Price, R., Sutherland, D., Westerlund, N., $\&$ Andre, C. (2004). Oil Price Developments: Drivers, Consequences and Policy Responses. OECD Economic Outlook, 76, 1-29. https://doi.org/10.2139/ssrn.651323

Dougher, R. (2015). Factors Affecting Oil and Product Prices. API. 1-24.

EIA. (2018). What Drives Crude Oil Prices? Available at: $\quad$ http://www.eia.gov/finance/markets/reports presentations/eia_what_drives_crude_oil_prices.pdf

Gulen, G., \& Foss, M. M. (2012). Factors are Impacting Oil Price. $C E E, 1-23$.

Guo, H., \& Kliesen, K. (2005), Oil Price Volatility and U.S. Macroeconomics Activity. Federal Reserve Bank of St. Louis Review, 87, 669-83. https://doi. org/10.20955/r.87.669-84

Gupta, E. (2008). Oil Vulnerability Index of Oil-importing Countries. Energy Policy, 36, 1195-211. https://doi. org/10.1016/j.enpol.2007.11.011

Gyagri, M., Amarfio, E. M., \& Marfo, S. (2017). Determinants of Global Pricing of Crude Oil-a Theoretical Review. International Journal of Pharmacology, Phytochemistry and Ethnomedicine, 3(3), 7-15.

Jain, K. (2013). Oil Price Volatility and its Impact on the Selected Economic Indicators in India. International Journal of Management and Social Sciences Research, 2(11), 63-70.

King, K., Deng, A., \& Metz, D. (2012). An Econometric Analysis of Oil Price Movements: The Role of Political Events and Economic News, Financial Trading, and Market Fundamentals. Bates White, 1-53. 
Punati, N., \& Raju, R. G. (2017). Determinants of Crude Oil Prices in India. International Journal of Economics and Management Studies. 4(10), 1-9. https://doi. org/10.14445/23939125/IJEMS-V4I10P101

Sadorsky, P. (1999). Oil Price Shocks and Stock Market Activity. Energy Economics, 21(5), 449-69. https://doi. org/10.1016/S0140-9883(99)00020-1

Sharma, A., Singh, G., Sharma, M., \& Gupta, P. (2014). Impact of Crude Oil Price on Indian Economy. International Journal of Social Science and Interdisciplinary Research, 1(4), 95-9.
Soni, A. (2014). Global Oil Markets and India's Vulnerability to Oil Shocks. TERI-NFA, 2014 Mar, 18.

Srithar, P., Bairavi, N., \& Mariselvam, G. (2015). Oil Price Volatility and its Impact on the Selected Economic Indicators in India. International Academic Research Journal of Economics and Finance, 3(4), 10-16.

The Government of Canada. (2010). Review of issues affecting the price of crude oil. Available at: http:// publications.gc.ca/site/archiveearchived.html?url=http:// publications.gc.ca/collections/collection_2011/rncannrcan/M164-2-2010-eng.pdf. 